\title{
Program CSR Berbasis Pemberdayaan Masyarakat Menuju Kemandirian Ekonomi Pasca Tambang di Desa Sarijaya
}

\author{
Asa Ria Pranoto ${ }^{1}$ \\ Dede Yusuf ${ }^{2}$
}

\begin{abstract}
Corporate Social Responsibility (CSR), is the company's commitment to contribute to sustainable economic development by taking into account the social aspects and the environment. PT Pertamina EP as one of the major industrial companies operating internationally and has a fundamental problem in the implementation of their CSR, namely how the planning and implementation of the CSR program, as well as through any indicator PT Pertamina EP is able to apply a good CSR refers to the MDGs documents, regulations regulations and ISO 26000. this study aimed to measure the efficiency of the implementation as well as the response and participation in the implementation of CSR programs conducted.
\end{abstract}

\section{Keywords:}

CSR; PT Pertamina EP; Effiscency Program CSR.

\begin{abstract}
Abstrak
Corporate Social Responsibility (CSR), adalah komitmen perusahaan dalam berkontribusi pada pengembangan ekonomi berkelanjutan dengan memerhatikan aspek sosial dan lingkungan. PT Pertamina EP sebagai salah satu perusahaan industri besar dan beroperasi secara internasional memiliki permasalahan mendasar dalam penerapan CSR, yaitu perencanaan dan pelaksanaan program CSR tersebut, serta indikator yang dipakai PT Pertamina EP agar mampu menerapkan CSR yang baik mengacu pada dokumen MDGs, perundang-undangan serta ISO 26000. Penelitian ini dimaksudkan untuk mengukur efisiensi pelaksanaan serta tanggapan dan keikutsertaan masyarakat dalam pelaksanaan program CSR yang dilakukan
\end{abstract}

\section{Kata Kunci:}

CSR; PT Pertamina EP; Efisiensi Program CSR.

\section{Pendahuluan}

Corporate Social Responsibility (CSR) adalah sebuah komitmen perusahaan atau dunia bisnis dalam memberikan kontribusi terhadap pengembangan ekonomi yang berkelanjutan, dan menitikberatkan pada perhatian aspek ekonomi, sosial, dan lingkungan (Ardianto, 2011:34). Di Indonesia, kewajiban dalam pelaksanaan CSR diatur dalam UU No. 40 Tahun 2007 tentang Perseroan Terbatas serta dalam PP

\footnotetext{
1 Staf CSR PT Pertamina EP Field Sanga-Sanga.

Email: asaria.90@gmail.com

2 Mahasiswa Teknik Industri, Fakultas Teknik, Universitas Mulawarman.

Email: dyusuf144@gmail.com
} 
No. 47 Tahun 2012 tentang Tanggung Jawab Sosial dan Lingkungan Perseroan Terbatas. Berdasarkan perundang-undangan tersebut, tanggung jawab sosial dan lingkungan adalah bentuk komitmen perseroan guna berperan serta dalam pembangunan ekonomi yang berkelanjutan, serta meningkatkan kualitas kehidupan dan lingkungan yang bermanfaat bagi perseroan secara internal dan eksternal, komunitas setempat, serta masyarakat secara umum.

Chairil (2007: 285) menyampaikan bahwa program CSR ditujukan agar para pelaku bisnis, baik sektor industri dan korporasi, dapat turut berperan dalam perutumbuhan ekonomi yang sehat, dengan memperhatikan faktor lingkungan hidup. Akan tetapi, dalam kesimpulan penelitian yang dilakukan Nursahid (2006: 26) ${ }^{3}$ pada tiga perusahaan BUMN , sebagian besar derma atau bantuan sosial diberikan ketika BUMN masih bersifat karitatif (charity) daripada filantropi.

Bantuan tersebut masih terfokus pada pemenuhan kebutuhan sesaat dan belum mampu menyentuh aspek-aspek strategis ekonomi pembangunan masyarakat disekitar wilayah kerja. Meskipun secara normatif penyelenggaraan CSR didorong oleh kesadaran akan tanggung jawab sosial, di dalam pelaksanaannya masih dibayangi oleh pencitraan positif dari perusahaan saja. Perusahaan secara garis besar belum memiliki sebuah perancaaan strategis atau cetak biru pelaksanaan program yang komprehensif, terhadap pelaksanaan program (Ardianto dkk, 2011).

Berdasarkan data yang dihimpun peneliti dari beragam sumber, memberikan gambaran bahwa pelaksanaan CSR di Indonesia sebagian besar masih berupa karitatif dan sebagai ajang pembentukan citra positif perusahaan. Belum sepenuhnya berupa keinginan untuk

3 Ardianto, Elvinaro dkk. (2011). Efek Kedermawawanan Pebisnis \& CSR. membangun sebuah perekonomian yang berkelanjutan, pada masyarakat sekitar wilayah operasinya. Hal ini sebenarnya merupakan bentuk paling primitif dari pelaksanaan tanggung jawab sosialnya.

PT Pertamina EP, sebagai salah satu National Oil Company, memiliki visi sebagai perusahaan World Class yang berkomitmen untuk berkontribusi dalam terwujudnya Millenium Development Goals (MDGs), salah satu target yang ingin dicapai adalah penurunan kemiskinan dan degradasi lingkungan di negara berkembang. Maka yang menjadi permasalahan dalam penelitian $\mathrm{n}$ ini adalah bagaimana pelaksanaan program CSR yang dilakukan PT Pertamina EP Field Sanga-Sanga, serta melalui indikator apa pelaksanaan program CSR tersebut sesuai dengan asas kebutuhan, manfaat, serta sejauh mana tingkat efisiensi pelaksanaan program dalam melibatkan masyarakat dalam partisipasi terhadap pelakasanaan program.

\section{CSR Secara Umum dan Perkembangannya}

CSR secara global tidak hanya dimaknai sebagai sebuah aktivitas derma atau karitatif atau sikap sukarela yang dilakukan pihak perusahaan. Namun, paradigma baru CSR mengarah pada sebuah bentuk komitmen suatu perusahaan, dalam melakukan tanggung jawab atau timbal balik (feed back) kepada masyarakat dan lingkungan, serta pembangunan ekonomi mandiri secara berkelanjutan.

Semisal memodifikasi business as usual dan pemberian kredit mikro yang khusus kepada masyarakat miskin sebagai bentuk "bisnis mengatasi kemiskinan" ${ }^{4}$. Lahirnya paradigma tersebut seiring dengan lahirnya konsep pembangunan berkelanjutan. Kesadaran tersebut lahir dan berkembang sebagai tugas dan tanggung jawab yang harus dilakukan, mengingat munculnya beragam konflik

\footnotetext{
4 Lingkar Studi CSR
} 
dan kesenjangan sosial antar tenaga dengan pemilik perusahaan, serta masyarakat disekitar lingkungan kerja.

Pada tahun-tahun awal perkembangan paradigma tersebut, CSR masih dipandang sebagai sebuah tanggung jawab sosial yang dilaksanakan secara primitif. Belum adanya sebuah standar baku pedoman pelaksanaan dan penilaian terhadap pelaksanaan CSR menjadi kendala utama dalam kesepemahaman konsep.

Pada tahun 2004, ISO selaku organisasi standardisasi mutu internasional berinisiatif untuk membentukworking group yang kemudian melahirkan panduan dan standardisasi pelaksanaan tanggung jawab perusahaan dalam bentuk ISO:26000. Titik kritis dalam dokumen standardisasi tersebut menekankan, social responsibility adalah titik penting dalam kelanjutan sebuah organisasi. Di dalam cakupan dokumen itu memuat beberapa isu pokok diantaranya adalah pengembangan masyarakat, konsumen, praktik kegiatan institusi yang sehat, lingkungan, ketenagakerjaan, hak asasi manusia, dan organizational governance.

\section{CSR dan Pencapaian MDGs bagi Perusahaan BUMN}

Millenium Development Goals (MDGs) merupakan langkah strategis yang ditetapkan di New York, Amerika Serikat pada tahun 2010, dalam pertemuan yang dihadiri oleh pejabat tinggi pemerintah, pebisnis, dan organisasi dunia tersebut menetapkan delapan target yang ingin dicapai dunia pada tahun 2015. Secara garis besar MDGs dimaksudkan untuk mengurangi separuh kemiskinan dan kelaparan pada tahun mendatang. Pihak swasta dan korporasi diikutsertakan dan diupayakan dapat memaksimalkan perannya dalam pelaksanaan tanggung jawab sosial dan lingkungan, dalam bentuk pelaksanaan CSR.

Akan tetapi dalam implementasinya, bentuk kewajiban ikut berperan aktif dalam CSR tersebut masih perlu mendapat perhatian kritis.
Sebagian besar korporat tetap melaksanaan CSR hanya sebagai bentuk santunan, dengan efek yang sesaat dan masih terpusat pada kebutuhan jangka pendek. Dalam permalasahan tersebut, pelaksanaan CSR yang masih sangat primitif dan menjadi ajang pencitraan korporasi terjebak pada kalimat "charity".

Pada gejolak permasalahan itu, tanggung jawab perusahaan BUMN terhadap pembangunan ekonomi sekitar diwujudkan dalam bentuk bina lingkungan, yang kemudian diatur dalam Kepmen BUMN No.236/ $\mathrm{MBU} / 2003$. Kepmen tersebut menyatakan bahwa dalam pelaksanaan CSR, perusahaan BUMN wajib melaksanaan program kemitraan dengan UKM, Usaha Skala Kecil, dan program bina lingkungan. Tujuan dari ditetapkannya peraturan tersebut adalah memberikan arah yang jelas, agar perusahaan dapat tetap berkomitmen pada kesepakatan dunia dalam mengentaskan kemiskinan dan pencapaian ISO 26000.

\section{Metodologi}

Metode penelitian yang digunakan pada penelitian ini adalah kualitatif. Difokuskan pada studi kasus dengan menganalisis fenomena sosial perencanaan dan pelaksanaan program CSR yang dilakukan PT Pertamina EP field Sanga-Sanga. Pengambilan data dilakukan dengan studi kepustakaan, observasi lapangan, wawancara, serta kajian teoritis pada penelitian yang pernah dilakukan dan dianggap relevan dengan permasalahan yang dikemukakan. Fokus penelitian ini ada tiga yaitu, pertama, tahapan pelaksanaan program CSR yang dilakukan PT Pertamina EP field Sanga-Sanga di Desa Sari Jaya, Kecamatan Sanga-Sanga, Kabupaten Kutai Kartanegara. Kedua, tanggapan dan tingkat partisipasi dari masyarakat di lokasi studi. Pengambilan data menggunakan human instrument dengan bantuan panduan wawancara. Ketiga, analisis tingkat keberhasilan, partisipasi dan manfaat yang didapatkan masyarakat di lokasi studi. 
Pengambilan data menggunakan pendekatan purposive sampling yang diwakili oleh kelompok Karang Taruna di lokasi studi.

Sugiyono (2006: 338) mengungkapkan bahwa validasi sebuah desain penelitian pada pengembangan sebuah program kerja, atau model dan produk harus melalui forum diskusi dengan beberapa informan yang relevan dan menguasai bidangnya. Dalam hal ini, desain penelitian yang dilakukan dihasilkan dari proses focus group discusion (FGD) dengan beberapa informan yang dianggap menguasai bidangnya.

\section{Latar Belakang dan Motif Program CSR PT Pertamina EP Field Sanga-Sanga}

Berdasarkan uraian sebelumnya, latar belakang pelaksanaan program CSR PT Pertamina EP Field Sanga-Sanga mengacu pada ISO 26000, yaitu konsisten dengan pembangunan yang berlanjutan dan tercapainya kesejahteraan rakyat, mempertimbangkan ekspektasi semua stakeholder, taat hukum dan konsisten dengan norma internasional, dan terintegrasi dengan kegiatan bisnis. Sementara itu, beberapa tujuan yang dijadikan motif pelaksanaan program secara eksternal adalah memberikan kontribusi dalam perbaikan indeks pembangunan manusia (IPM) Indonesia, melalui pelaksanaan program-program yang mensukseskan tercapainya MDGs.

Sedangkan secara internal pelaksanaan program tersebut adalah membangun hubungan yang harmonis dan kondusif dengan pemangku kepentingan (stakeholder) yang ada, guna turut berkontribusi dalam pencapaian tujuan korporasi terutama dalam membangun reputasi. Visi pelaksanaan program "Menuju Kehidupan Lebih Baik", dengan kriteria pelaksanaan meliputi lima kriteria pelaksanaan, mencakup kepentingan bersama antara pemerintah, komunitas dan perusahaan, serta memenuhi asas manfaat, berkelanjutan pada wilayah di dekat wilayah operasi, publikasi dan mendukung PROPER.
Main issue atau dalam pelaksanaan program adalah pelibatan dan pengembangan masyarakat, yang kemudian difokuskan pada empat pilar utama, yaitu Pemberdayaan Ekonomi Masyarakat, Program Kesehatan, Pendidikan, dan Ecopreneurship. Isu utama tersebut dikembangkan berdasarkan karakteristik wilayah kerja di masing-masing wilayah, oleh unit operasi atau anak perusahan dan Pertamina Foundation.

Pengembangan program kemudian diselaraskan dengan tujuan program Pertamina Sobat Bumi. ${ }^{5}$ Hal tersebut mengisyaratkan bahwa setiap program yang dilaksanakan harus dirancang berdasarkan hasil pemetaan sosial, ekonomi, dan lingkungan pada daerah operasi. Secara garis besar uraian main issue tersebut adalah seperti pada Tabel 1.

\section{Pelaksanaan Program CSR PT Pertamina EP Field Sanga-Sanga}

Program Hati Kertajaya merupakan program CSR yang digagas oleh PT Pertamina EP Field Sanga-Sanga. Program tersebut berbentuk usaha pembinaan kepada kelompok Karang Taruna di Desa Sarijaya. Pusat kegiatan difokuskan di Kelurahan Sarijaya, Kecamatan Sanga-Sanga. Progam ini merupakan salah satu unggulan dari implementasi program CSR yang dilaksanakan PT Pertamina EP Field Sanga-Sanga. Berdasarkan hasil observasi lapangan serta kajian pustaka yang dilakukan, pelaksanaan program tersebut mengandung prinsip triple bottom line yang berorientasi pada pembangunan yang berkelanjutan.

John Elkington dalam Enjang (2012: 6) menyampaikan bahwa intisari dari pelaksanaan CSR memuat tiga pilar utama pembangunan yaitu orang, planet, dan keuntungan, yang

\footnotetext{
Pertamina Sobat Bumi adalah tema utama CSR yang dijadikan acuan oleh semua Unit Operasi atau Anak Perusahaan di bawah naungan Pertamina dan Pertamina Foundation. Launching pertama kali di Kamojang pada tanggal 1 Desember 2011 oleh Direktur Utama.
} 
Tabel 1.

Uraian Isu Utama Pelaksanaan CSR/TJSL Pertamina EP

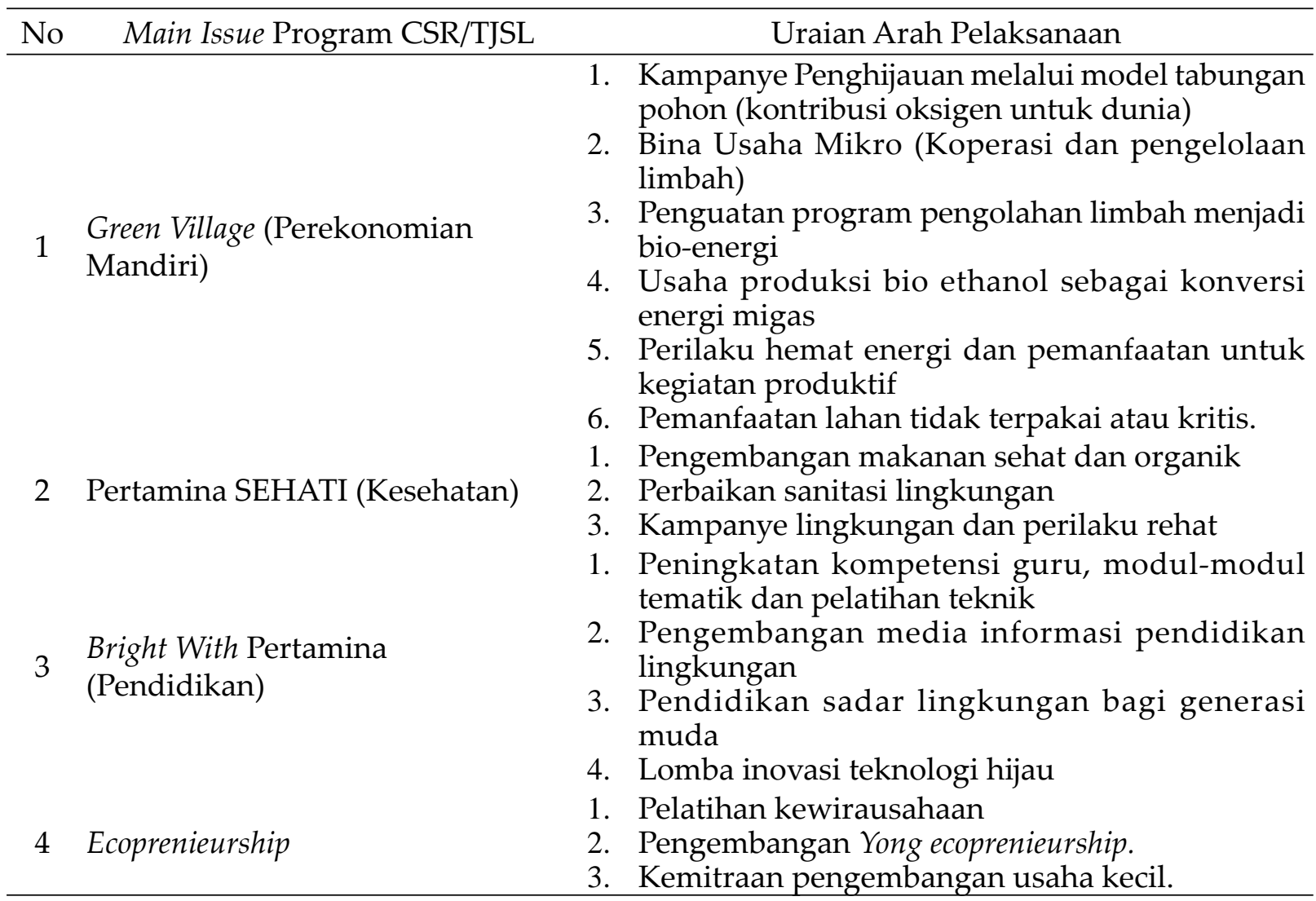

Sumber : Data Sekunder (Main Issue Pertamina SOBAT BUMI)

merupakan tujuan utama dari pelaksanaan pembangunan. Mengacu pada prinsip pemikiran tersebut, implementasi program CSR dimulai pada tahun 2011 melalui beberapa tahapan:

\section{Tahap Perencanaan Program}

Berdasarkan hasil social maping yang dilakukan PT Pertamina EP Field Sanga-Sanga, bekerja sama dengan Pusat Studi Pedesaan dan Kawasan Universitas Gajah Mada, Desa Sarijaya yang terletak di kawasan pesisir Kabupaten Kutai Kartanegara memiliki potensi di sektor budi daya ikan air tawar, peternakan, dan perkebunan. Hal tersebut juga didukung dengan adanya potensi kelompok Karang Taruna yang berperan aktif dalam pemberdayaan dan kegiatan-kegiatan kemasyarakatan, baik di tingkat kelurahan maupun kabupaten.
Beberapa prestasi telah diraih, serta adanya program kegiatan masyarakat desa oleh Karang Taruna sebagai inisiator. Maka berdasarkan hasil telaah tersebut, PT Pertamina EP Field Sanga-Sanga mulai merintis program bantuan dan kerja sama guna mempersiapkan kehidupan ekonomi masyarakat yang mandiri di wilayah kerjanya. Terutama pasca anjloknya perekonomian masyarakat yang bertumpu pada sektor pertambangan, terutama pertambangan batu bara beberapa periode lalu, baik yang dikelola perusahaan skala nasional maupun perusahaan tambang rakyat.

Kondisi awal usaha budi daya keramba ikan air tawar Karang Taruna Desa Sarijaya ini memiliki berbagai kendala dan keterbatasan. Selain kondisi para pelaku usaha dan anggota yang belum memiliki kompetensi dalam bidangnya, juga keterbatasan sarana dan 
prasarana penunjang usaha. Sarana dan prasarana pada kondisi awal ini diantaranya kurangnya instrumen kayu dan bahan baku lainnya yang digunakan untuk kerangka keramba, serta kurangnya modal yang dimiliki untuk membeli bibit ikan dan pakan ikan yang masih relatif mahal. Masalah ketersediaan sumber daya manusia yang berkompeten juga menjadi kendala utama. Hal ini disebabkan mayoritas latar belakang pekerjaan masyarakatnya adalah pekerja ataupun buruh lepas perusahaan tambang.

Untuk mengatasi hal tersebut, langkah pertama yang dilakukan PT Pertamina EP Field Sanga-Sanga mulai menyusun tahapan pelaksanaan dan implementasi dari Program CSR Hati Kertajaya. Mengacu pada dokumendokumen program CSR seperti MDGs dan ISO 26000, serta empat pilar utama pelaksanaan CSR/TJSL sebagai main issue, maka dilakukan pertemuan secara langsung antara pihak korporasi dan masyarakat. Pertemuan bertujuan untuk diskusi mendalam guna mengetahui kebutuhan awal dari masyarakat Desa Sarijaya, dengan diwakili oleh pengurus dan anggota Karang Taruna.

Setelah diketahui pasti permasalahan dan kendala yang dihadapi di lapangan, dilakukan perumusan visi dan misi program, serta target dan strategi pelaksanaan program termasuk didalamnya penyesuaian visi dan misi perusahaan, kebijakan pimpinan, rancangan program, ketersediaan SDM, pemetaan wilayah, alokasi dana, serta strategi implementasi dan evaluasi.

\section{Tahap Impelentasi Program CSR}

Setelah tahap perencanaan dilakukan, termasuk didalamnya strategi implementasi, alokasi dana dan evaluasi program, PT Pertamina EP Field Sanga-Sanga mengirimkan lima warga Sarijaya sebagai perwakilan masyarakat, untuk mengikuti pelatihan budi daya keramba ikan air tawar secara modern. Pelatihan dilaksanakan oleh Balai Pelatihan
BudiDaya Ikan Air Tawar Kabupaten Sukabumi, Jawa Barat tahun 2011. Hal ini dilakukan untuk memberikan pelatihan dan pembekalan kemampuan (skiil) awal pelaksanaan program budi daya yang direncanakan.

Setelah mengikuti pelatihan tersebut, sisa modal yang ada dimanfaatkan untuk membangun keramba awal sebanyak 20 unit, setiap unit diisi 500 bibit ikan. Masyarakat yang telah memiliki bekal pengetahuan hasil pelatihan tersebut berperan aktif dalam mentransfer pengetahuan yang telah didapat kepada warga lainnya. Kemudian pelaksanaan program diberikan prioritas kepada Karang Taruna Sarijaya, akan tetapi pendampingan, pengawasan dan bantuan program tetap dilaksanakan PT Pertamina EP Field Sanga-Sanga.

Hal ini dilakukan untuk menciptakan iklim mandiri pada masyarakat setempat. Pada tahun 2012, jumlah warga yang mengikuti program tersebut bertambah menjadi 11 orang, dan pada tahun 2013 jumlah anggota aktif mencapai 20 orang dengan jumlah keramba ikan sebanyak 135 unit. Positive impact yang diperoleh dari pelaksanaan program CSR tersebut adalah masyarakat mulai belajar dan ikut terlibat pada usaha budi daya ikan air tawar yang ada.

Hal ini menjadi pemicu terciptanya penggerak utama perekonomian masyarakat di wilayah kerja perusahaan, dan mulai bertransisi dengan tidak lagi semata-mata bersumber dari penghasilan sebagai pegawai. Dengan kata lain, pelaksanaan program CSR mampu menjadi pemicu inisiatif dan pilot reference bagi masyarakat lainnya. Kondisi tersebut menjadi capaian prestasi tersendiri dari pelaksanaan CSR yang telah dilaksanakan PT Pertamina EP Field Sanga-Sanga.

Pada tahun 2013, pendampingan dan bantuan terhadap pelaksanaan program difokuskan pada pendampingan dan pelatihan pembuatan pellet pakan ikan organik, menggunakan mesin pembuat pakan ikan yang diberikan. Hal ini dilakukan untuk 
menurunkan cost produksi yang ada karena harga pakan ikan dipasaran relatif tinggi. Hasil analisis kelayakan industri yang dilakukan juga menunjukan pengurangan biaya produksi sebesar 47.82 perse dapat termaksimalkan.

Dampak (outcome) lain yang dihasilkan adalah adanya diversifikasi usaha produksi pakan ikan organik dengan memanfaatkan limbah kepala udang dari pabrik udang di sekitar tambak. Hal ini juga diharapkan mampu menciptakan unit pelaksana program baru yang akan menyerap tenaga kerja baru, serta menyediakan pasar kebutuhan pokok usaha keramba budi daya ikan air tawar, serta terciptanya sebuah kesinambungan antara program yang ada.

\section{Tahap Evaluasi Program}

Dalam pelaksanaan CSR tersebut, PT Pertamina EP Field Sanga-Sanga selalu memantau hasil capaian program dan melakukan perbaikan pada beberapa sektor kerja yang belum termaksimalkan. Tujuan dari dilakukannya evaluasi tersebut guna mendapatkan data dan informasi terkait hambatan dan permasalahan yang ada di lapangan, serta solusi mengatasinya agar program dapat berjalan maksimal.

Hadi (2011) dalam Enjang (2012 : 11) menyatakan dalam evaluasi pelaksanaan program tanggung jawab sosial perusahaan, dilakukan dalam rangka mencapai beberapa tujuan, diantaranya adalah memperoleh data dan informasi guna memaksimalkan pelaksanaan program kegiatan, memperoleh berbagai bahan pertimbangan yang dijadikan salah satu acuan dalam pengambilan keputusan layak atau tidaknya sebuah program CSR dilanjutkan, serta memperoleh rekomendasi perbaikan program. Selain itu juga bertujuan untuk memperoleh data dan informasi faktual terkait hambatan program yang dilaksankan, memperoleh alternatif solusi terhadap hambatan program yang dilaksanakan, dan mendapatkan rekomendasi dan pelaporan pada estimasi penggunaan dana bantuan program yang dilaksanakan.

Data dan informasi yang didapatkan dari evaluasi yang dilakukan dijadikan acuan dalam pemantapan dan penetapan kebijakan. Pelaksanaan evaluasi juga dipandang mampu meningkatkan capaian program dan optimalisasi dana serta waktu pelaksanaan program yang telah berjalan. Adapun secara garis besar hasil observasi terhadap kendala dan solusi yang direkomendasikan dalam pelaksanaannya adalah seperti pada Tabel 3.

\section{Tanggapan dan Partisipasi dari Masyarakat}

Tanggapan dan partisipasi masyarakat dalam pelaksanaan program CSR menjadi penentu utama dari indeks keberhasilan program, terutama pada program yang berbasis pengembangan ekonomi mandiri dan pemberdayaan masyarakat. Partisipasi dan inisiatif dari masyarakat secara penuh dan adanya sinergi antara dua pihak dapat menjadi faktor optimalisasi pelaksanaan program.

Menurut Ardianto (2011: 92) adanya partisipasi masyarakat sebagai pemicu kemandirian dan proses pemberdayaan adalah komponen yang sangat penting. Proses tersebut dilakukan secara akumulatif sehingga semakin banyak keterampilan, atau semakin tingginya kompetensi yang dimiliki seseorang maka semakin tinggi kemampuannya berpartisipasi.

Berdasarkan hasil wawancara dan studi observasi lapangan, dapat diketahui respons dan tingkat partisipasi masyarakat dalam pelaksanaan program cukup tinggi. Hal ini ditunjukkan oleh semakin banyaknya masyarakat yang mulai terlibat dalam pelaksanaan program. Terlebih setelah diberikannya bantuan tambahan pada mesin produksi pakan ikan, dan beberapa program pendampingan pada anggota masyarakat yang baru memulai usaha budi daya.

Tingginya angka partisipasi juga dapat terlihat dari mulainya masa transisi masyarakat dalam menjadikan usaha budi daya keramba 
Tabel 3.

Matrik Kendala dan Solusi Program CSR Keramba Ikan Air Tawar Desa Sarijaya

\begin{tabular}{|c|c|c|c|c|}
\hline Kendala & Uraian Kendala & $\begin{array}{c}\text { Sudah } \\
\text { dilakukan }\end{array}$ & $\begin{array}{c}\text { Belum } \\
\text { dilakukan }\end{array}$ & Alternatif Solusi \\
\hline $\begin{array}{l}\text { Masih } \\
\text { terbatasnya } \\
\text { jumlah SDM } \\
\text { dari pihak } \\
\text { korporasi }\end{array}$ & $\begin{array}{l}\text { Diperlukannya } \\
\text { minimal satu } \\
\text { orang yang fokus } \\
\text { dalam pelaksanaan } \\
\text { perkembangan } \\
\text { pelaksanaan program } \\
\text { dengan uraian jobdesk } \\
\text { sebagai mediator dan } \\
\text { fasilitator }\end{array}$ & $\begin{array}{l}\text { Pelaksanaan } \\
\text { dan } \\
\text { pengawasan } \\
\text { dilakukan } \\
\text { langsung oleh } \\
\text { staf Humas }\end{array}$ & $\begin{array}{l}\text { Belum } \\
\text { ditetapkan } \\
\text { atau di } \\
\text { tunjuknya satu } \\
\text { orang yang } \\
\text { melakukan } \\
\text { jobdesk seperti } \\
\text { yang telah di } \\
\text { uraikan. }\end{array}$ & $\begin{array}{l}\text { Menunjuk atau } \\
\text { menetapkan satu } \\
\text { orang fasilitator } \\
\text { dan mediator } \\
\text { yang memahami } \\
\text { kondisi pada lokasi } \\
\text { program, dan mampu } \\
\text { menjembatani } \\
\text { kepentingan dari } \\
\text { semua stakeholder. }\end{array}$ \\
\hline $\begin{array}{l}\text { Sarana \& } \\
\text { Prasarana }\end{array}$ & $\begin{array}{l}\text { Optimalisasi program } \\
\text { dibutuhkan beberapa } \\
\text { sarana dan prasarana } \\
\text { penunjang seperti } \\
\text { menambah unit } \\
\text { keramba, bangunan } \\
\text { tambak, tempat } \\
\text { produksi pakan ikan } \\
\text { dan papan nama } \\
\text { usaha }\end{array}$ & $\begin{array}{l}\text { Penyediaan } \\
\text { alat pembuat } \\
\text { pakan ikan } \\
\text { dan tempat } \\
\text { penyimpanan } \\
\text { dan } \\
\text { produksinya }\end{array}$ & $\begin{array}{l}\text { Papan nama } \\
\text { usaha di } \\
\text { sekitar wilayah } \\
\text { keramba ikan }\end{array}$ & $\begin{array}{l}\text { Menambah unit } \\
\text { keramba ikan untuk } \\
\text { meningkatkan laba } \\
\text { yang didapatkan, } \\
\text { serta pembuatan } \\
\text { papan nama disekitar } \\
\text { wilayah kerja budi } \\
\text { daya ikan. }\end{array}$ \\
\hline Publik & $\begin{array}{l}\text { Adanya mediasi } \\
\text { dengan beberapa } \\
\text { media cetak dan } \\
\text { digital untuk } \\
\text { menyampaikan } \\
\text { pelaksanaan program } \\
\text { dan capaian yang } \\
\text { telah di lakukan, } \\
\text { tujuan dan } \\
\text { perkembangannya } \\
\text { sehingga masyarakat } \\
\text { ataupun pihak } \\
\text { lain dapat ikut } \\
\text { berkontribusi }\end{array}$ & $\begin{array}{l}\text { Publikasi } \\
\text { masih } \\
\text { dilaksanakan } \\
\text { secara internal } \\
\text { melalui media } \\
\text { internal seperti } \\
\text { majalah } \\
\text { dan tabloid } \\
\text { Pertamina, } \\
\text { serta secara } \\
\text { digital melalui } \\
\text { media portal }\end{array}$ & $\begin{array}{l}\text { Publikasi } \\
\text { melalui media } \\
\text { lokal maupun } \\
\text { nasional, } \\
\text { booklet, majalah } \\
\text { dinding di } \\
\text { lokasi strategis } \\
\text { serta expo budi } \\
\text { daya ikan dan } \\
\text { perairan yang } \\
\text { kontemporer }\end{array}$ & $\begin{array}{l}\text { Pengaktivan } \\
\text { publikasi hasil } \\
\text { capaian kerja, serta } \\
\text { perkembangannya } \\
\text { sehingga } \\
\text { memungkinkan } \\
\text { di konsumsi lebih } \\
\text { luas. Hal tersebut } \\
\text { dipandang mampu } \\
\text { mengundang iklim } \\
\text { investasi serta sebagai } \\
\text { salah satu cara } \\
\text { perluasan pangsa } \\
\text { pasar hasil produksi }\end{array}$ \\
\hline
\end{tabular}

Sumber : Diolah dari data primer

ikan air tawar sebagai mata pencaharian utama. Secara garis besar tingginya tingkat partisipasi masyarakat dalam pelaksanaan program dibagi menjadi tiga kuadran kategori, yaitu : tingkat partisipasi tinggi, tingkat partisipasi sedang, dan tingkat partisipasi rendah.

Pada tingkat partisipasi tinggi artinya masyarakat secara aktif terlibat menjadi pengelola program, tingkat partisipasi sedang adalah masyarakat yang hanya melakukan pada beberapa sub-sektor pelaksanaan program seperti membuat unit keramba, pembuatan pakan ikan, dan pemasaran hasil budi daya. Sedangkan pada tingkat partisipasi rendah adalah masyarakat yang bertindak sebagai anggota pasif dalam arti hanya terlibat pada 


\section{Gambar 1.}

Persentase Tingkat Partisipasi Masyarakat (persen)

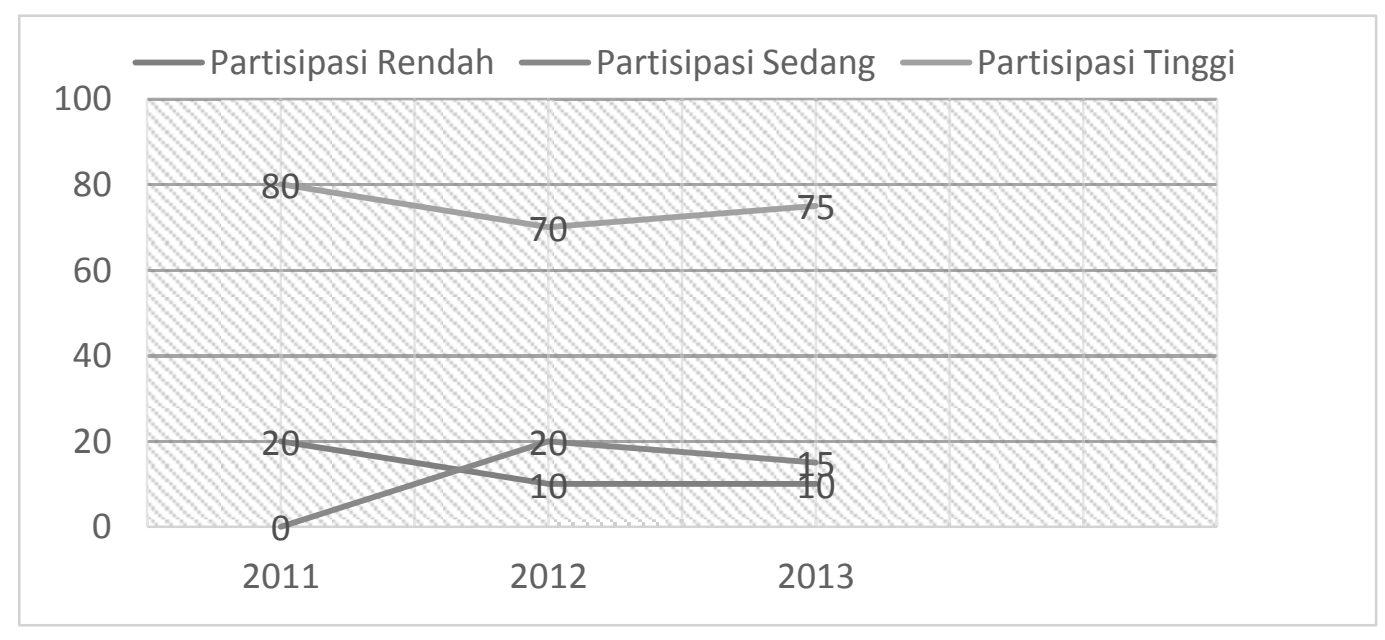

Sumber : Diolah dari data primer

budi daya ikan air tawar, sedangkan untuk unit dan bibit ikan di adakan sendiri menggunakan dana pribadi. Secara lebih jelas disajikan pada gambar 1.

Hasil olahan data tersebut memberikan gambaran bahwa pada tahun 2011, tingkat partisipasi masyarakat pada pelaksanaan program sangat tinggi yaitu 80 persen. Hal ini karena pelaksanaan awal program, jumlah anggota masyarakat yang aktif masih relatif sedikit, serta merupakan perintis awal program sehingga intensitas pelaksanaan dan pelaksanaan kegiatan dapat lebih mudah dilakukan. Pada perkembangan tahun 2012, seiring dengan bertambahnya jumlah anggota masyarakat yang ikut terlibat,tingkat partisipasi masyarakat cenderung menurun sebesar 10 persen, diikuti partisipasi rendah menurun sebesar 10 persen.

Hal tersebut disebabkan bertambahnya jumlah anggota yang ada, sehingga masih berada dalam fase pembelajaran dan penjajakan usaha. Pada tahun 2013, tingkat partisipasi tersebut meningkat 5 persen karena kompetensi yang dimiliki anggota baru yang terlibat semakin bertambah, setelah satu tahun menjalankan program. Pola pendampingan dan bantuan yang diberikan PT Pertamina EP Field
Sanga-Sanga serta kerja sama dan inisiatif dari anggota masyarakat yang telah lama terlibat mampu bersinergi dan mengoptimalkan pelaksanaan program.

Pada aspek respons dan tanggapan dari masyarakat, secara umum dilakukan pendekatan yang persuasif dan objektif dari peneliti. Menggunakan pola evaluasi formatif yang secara umum digunakan sebagai salah satu cara mengukur indeks capaian pelaksanaan sebuah program. Dalam langkah kerja pelaksanaannya, desain evaluasi formatif bertujuan untuk memberikan gambaran sejauh mana program tersebut dapat terlaksana, baik dari sudut pandang masyarakat sebagai informan peneltiian, maupun dari sudur pandang peneliti sebagai evaluator.

Langkah-langkah tersebut dilakukan untuk memperoleh informasi dan data yang valid serta tingkat objektivitas penilaian pada pelaksanaan program CSR yang telah dilakukan. Penilaian respons masyarakat yang dilakukan juga bertujuan untuk melihat substansi pelaksanaan program CSR yang telah direncanakan, serta mengukur dampak yang dirasakan oleh masyarakat. Secara garis besar tahapan evaluasi dilakukan dengan menguraikan aspek yang ingin diukur dari 
Tabel 4.

Uraian Aspek yang Ingin Diukur

\begin{tabular}{ccl}
\hline No & $\begin{array}{c}\text { Aspek yang ingin } \\
\text { diukur }\end{array}$ & \multicolumn{1}{c}{ Uraian } \\
\hline 1 & Aspek Manfaat & $\begin{array}{l}\text { Program bantuan yang diberikan dapat langsung memberikan } \\
\text { dampak pada masyarakat. } \\
\text { Program bantuan sesuai dengan kebutuhan masyarakat. }\end{array}$ \\
2 & Aspek Kesesuaian & $\begin{array}{l}\text { Program pendampingan yang diberikan kepada peningkatan skill } \\
\text { dan kemampuan SDM masyarakat dalam mengelola usaha yang } \\
\text { dijalankan. }\end{array}$ \\
3 & Aspek Keberlanjutan & $\begin{array}{l}\text { Program bantuan yang diberikan dapat membantu masyarakat } \\
\text { dalam pemberdayaan ekonomi mandiri yang menunjang kehidupan } \\
\text { sehari-hari. }\end{array}$ \\
\hline
\end{tabular}

Sumber : Data Sekunder

Tabel 5.

Matrik Kerja Pengumpulan Data

\begin{tabular}{|c|c|c|c|}
\hline \multirow{2}{*}{ Tujuan } & \multicolumn{2}{|c|}{ Data Primer } & \multirow{2}{*}{ Data Sekunder } \\
\hline & Wawancara & Observasi & \\
\hline $\begin{array}{l}\text { Data yang } \\
\text { berhubungan } \\
\text { dengan } \\
\text { program CSR } \\
\text { yang dilakukan }\end{array}$ & $\begin{array}{l}\text { Alat: Pedoman } \\
\text { wawancara } \\
\text { Substansi : seluruh } \\
\text { informasi terkait } \\
\text { program yang } \\
\text { dijalankan } \\
\text { Informan : para } \\
\text { pelaku usaha, tokoh } \\
\text { masyarakat }\end{array}$ & $\begin{array}{l}\text { Alat: pedoman } \\
\text { observasi dan } \\
\text { dokumentasi } \\
\text { Cara kerja : Catatan } \\
\text { kecil yang berisi } \\
\text { ringkasan wawancara } \\
\text { yang dilakukan } \\
\text { Substansi : informasi } \\
\text { yang dianggap relevan } \\
\text { terhadap penelitian }\end{array}$ & $\begin{array}{l}\text { Alat: Data-data } \\
\text { sekunder seperti } \\
\text { laporan perusahaan dan } \\
\text { organisasi. } \\
\text { Substansi : data-data } \\
\text { penunjang berkenaan } \\
\text { dengan kegiatan CSR } \\
\text { yang dilakukan } \\
\text { Sumber : Perusahaan, } \\
\text { tokoh masyarakat }\end{array}$ \\
\hline
\end{tabular}

Sumber : Adaptasi (Prayogo, 2011)

program tersebut diantaranya aspek manfaat, aspek kesesuaian, aspek keberlanjutan, dan aspek dampak. (Dale, 2004) dalam Prayogo (2011) menyampaikan uraian empat aspek perencanaan evaluasi capaian program yang baik tersebut adalah seperti pada Tabel 4 .

Adapun tahapan implementasinya, dilakukan terhadap sejumlah kelompok masyarakat yang dijadikan responden dan informan. Penetapan responden tersebut menggunakan pendekatan purposive sampling terhadap beberapa orang yang dijadikan informan, dan dianggap memiliki peran yang relevan terhadap pelaksanaan program yang dilakukan. Matriks kerja pengumpulan data disajikan pada tabel 5 .
Hasil analisis evaluasi terhadap pelaksanaan program menunjukan bahwa secara keseluruhan, program CSR pada budi daya keramba ikan air tawar di Desa Sarijaya, yang dilaksanakan PT Pertamina EP Field Sanga-Sanga cukup berhasil dengan indeks capaian diatas angka 85 persen, jika dinilai dari empat aspek yang digunakan. Pada aspek manfaat diketahui sebesar 83.75 persen program bantuan yang diberikan dapat langsung memberikan manfaat pada masyarakat.

Pada aspek kesesuaian, indeks capaian program mencapai 80 persen, artinya program bantuan tersebut sesuai dengan kebutuhan masyarakat. Program pendampingan yang dilakukan memiliki nilai indeks sebesar 82.5 
Tabel 6.

Penetapan Indeks Capaian Program

\begin{tabular}{|c|c|c|c|c|c|c|c|c|c|c|}
\hline \multirow{2}{*}{$\begin{array}{l}\text { Capaian } \\
\text { Program }\end{array}$} & \multicolumn{2}{|c|}{$\begin{array}{c}\text { Aspek } \\
\text { Manfaat }\end{array}$} & \multicolumn{2}{|c|}{$\begin{array}{c}\text { Aspek } \\
\text { Kesesuaian }\end{array}$} & \multicolumn{2}{|c|}{$\begin{array}{c}\text { Aspek } \\
\text { Keberlanjutan }\end{array}$} & \multicolumn{2}{|c|}{$\begin{array}{c}\text { Aspek } \\
\text { Dampak }\end{array}$} & \multicolumn{2}{|c|}{ Rata-Rata } \\
\hline & $\mathrm{A}$ & $\mathrm{B}$ & $\mathrm{A}$ & $\mathrm{B}$ & A & $\mathrm{B}$ & $\mathrm{A}$ & $\mathrm{B}$ & $\mathrm{A}$ & $\mathrm{B}$ \\
\hline Skc & 3.7 & 3 & 3.4 & 3 & 3.6 & 3 & 3.6 & 4 & 3.57 & 3.25 \\
\hline Dalam (persen) & 92.5 & 75 & 85.00 & 75.00 & 90.00 & 75.00 & 90.00 & 100 & 89.38 & 81.25 \\
\hline$(\mathrm{A}+\mathrm{B}) / 2$ & \multicolumn{2}{|c|}{83.75 persen } & \multicolumn{2}{|c|}{80 persen } & \multicolumn{2}{|c|}{82.5 persen } & \multicolumn{2}{|c|}{95 persen } & \multicolumn{2}{|c|}{85.32 persen } \\
\hline
\end{tabular}

Ket : $A=$ Nilai dari responden, $B=$ Penilaian dari peneliti (evaluator)

Sumber : Diolah dari data primer

persen dalam meningkatkan kemampuan SDM dan peningkatan teknologi alat kerja. Pada aspek dampak, 95 persen mampu memberdayakan masyarakat membangun ekonomi mandiri yang berkesinambungan.

Maka dapat dikatakan bahwa secara keseluruhan program CSR yang dilaksanakan PT Pertamina EP Field Sanga-Sanga telah terlaksana secara proporsional pada tiap aspeknya, baik secara manfaat, kesesuaian, keberlanjutan, dan aspek dampak yang dihasilkan. Secara garis besar sajian hasil evaluasi dan indeks capaian program CSR yang dilakukan adalah seperti pada Tabel 6.

Berdasarkan sajian dari tabel 3 tersebut, dapat terlihat bahwa kesenjangan antara penilaian dari responden terhadap penilaian dari peneliti memiliki margin yang sangat kecil $(<0.5)$, sehingga indeks evaluasi program dapat dikatakan valid dan rasional, serta tingkat objektivitas yang tinggi. Lebih jauh, pada tiap butir aspek yang diukur skor maupun capaian yang dinilai responden pada butir 1, 2, dan 3 lebih tinggi dari skor yang diberikan peneliti. Akan tetapi pada butir 4 yaitu aspek dampak skor yang diberikan peneliti lebih tinggi dari yang diberikan responden. Hal ini terjadi karena adanya perbedaan stock knowledge, kepentingan maupun harapan yang dimiliki peneliti dan responden.

\section{Kesimpulan}

Berdasarkan hasil yang telah didapatkan tersebut, maka dapat disimpulkan bahwa pelaksanaan program CSR PT Pertamina EP Field Sanga-Sanga berbasis pengembangan perekonomian yang mandiri pasca kebergantungan pada dunia pertambangan di Sarijaya, dilaksanakan sesuai dengan nilainilai CSR yang berprinsip triple bottom line. Hal tersebut selaras dengan acuan dasar pelaksanaan yaitu ISO 26000 yang menitikberatkan pada aspek ekonomi mandiri serta main issue yang diterapkan pihak pimpinan.

Program CSR tersebut dilaksanakan melalui tiga tahap utama, yaitu tahap perencanaan, tahap implementasi, dan tahap evaluasi. Pada tingkat respons dan partisipasi yang diberikan masyarakat juga relatif tinggi dan adanya kontribusi yang optimal dari pihak masyarakat dan perusahaan sehingga indeks capaian program juga tinggi dengan indeks capaian program mencapai 85.32 persen, pengukuran capaian tersebut menggunakan pendekatan pada empat aspek yang dijadikan indikator yaitu aspek kesesuaian 80 persen, manfaat 83,75 persen, keberlanjutan 82,5 persen, dan dampak yang dihasilkan sebesar 95 persen mampu memberdayakan masyarakat membangun ekonomi mandiri yang berkesinambungan.

Adapun saran yang dapat diberikan pada penelitian yang dilakukan ini adalah pengembangan penelitian serupa dengan mengukur dimensi yang berbeda, baik secara kuantitatif maupun kualitatif sehingga dapat menyempurnakan kerangka evaluasi yang dilakukan. 


\section{Daftar Pustaka}

Ardianto, Elvriano dkk. (2011). Efek Kedermawanan Pebisnis dan CSR Berlilipatlipat. Jakarta: Elex Media Komputindo.

Badan Pusat Statistik Kabupaten Kutai Kartanegara. (2012). Kecamatan SangaSanga Dalam Angka. BPS Kab.Kukar. http:// www.kukar.bps.go.id/data/publikasi_66/ publikasi/files/kec.sanga_sanga_dlm_ angka. Diakses tanggal 10 Mei 2014.

Irawan, Enjang Pera. (2011). Program CSR Berbasis Pemberdayaan Masyarakat Pada PT PLN. Jurnal Tesis tidak diterbitkan. Universitas Padjadjaran.

Lingkar Studi CSR Indonesia. (18 Juli 2013). Pembangunan Berkelanjutan, Tanggung Jawab Sosial Perusahaan (CSR) dan Penanganan Kemiskinan. Disampaikan pada diskusi publik :Akuntabilitas Sosial CSR Industri Ekstraktif dan Perannya Dalam Penanggulangan Kemiskinan Berdasarkan ISO 26000; 2010 Gudance On Social Responsibility. Jakarta: PWYP Indonesia.

Prayogo, Dody. (2011). Evaluasi Program Corporate Social Responsibility dan Community Development Pada Industri Tambang dan Migas. Vol.15, No.1, hal 43-58

Siregar, Chairil N. (2007) Analisis Sosialogis Terhadap Implementasi Corporate Social Responsibility Pada Masyarakat Indonesia. Jurnal Sosioteknologi, Edisi 12 Tahun 6.

Sugiyono. (2006). Metode Penelitian Kuantitatif, Kualitatif dan $R \&$ $D$. Jakarta: Alfabeta Untung, Budi Hendrik, (2009). Coorporate Social Responsibility. Jakarta: Sinar Grafika. 